\title{
Ecological and Economic Aspects of Efficiency of the Use of Land Resources
}

\author{
Alexander Dubovitski ${ }^{1}$, Elvira Klimentova ${ }^{1, *}$, Alexander Nikitin ${ }^{1}$, Vadim Babushkin ${ }^{1}$, and \\ Natalya Goncharova ${ }^{1}$ \\ ${ }^{1}$ Michurinsk State Agrarian University, 393760, Internationalnaya str., 101, Michurinsk, Russia
}

\begin{abstract}
The aim of the study is the formalization of the balance method with respect to the determination of the ecological and economic efficiency of the use of land resources. During the research, the following methods were used: statistical-economic, monographic, balance, computational and constructive. In the sphere of environmental protection, there is usually uncertainty about benefits and uncertainty about costs. Therefore, at the moment, further formalization of the assessment of the processes taking place in the system of interaction between man and land in the process of agricultural production is required. When analyzing the effectiveness of the use of agricultural land, it is important to determine not only economic, but also environmental and economic components. The ecological component of land use can be measured on the strength of the amount of prevented environmental damage applied to soil fertility, and the magnitude of the ecological effect that is created when carrying out measures to reproduce soil fertility. As the studies show, cultivating agricultural crops causes a negative balance of nutrients in the soil, and the calculation of environmental and economic efficiency indicates the need not only for joint application of organic and mineral fertilizers in optimal parameters, but also for finding alternative ways of ensuring reproduction of soil fertility.
\end{abstract}

\section{Introduction}

An analysis of the current state of the natural environment and agricultural production, an assessment of the dynamics of changes in soil quality indicators give reason to say that the trend towards a decrease in land fertility and a deterioration in the overall environmental situation in the agricultural sector continues.

Soil is a source of nutrients necessary for plant growth, and in itself is the result of organic processes of living organisms, therefore, its condition varies widely, which is often characterized by degradation. According to the FAO (Food and Agricultural Organization) definition, soil degradation is a reduction in their ability to provide ecosystem goods and services and perform its functions over a period of time in the interests of the beneficiaries of these functions.

\footnotetext{
*Corresponding author: klim1-408@yandex.ru
} 
Soil degradation is manifested in various forms: for example, in such as soil erosion, soil salinization, soil nutrient depletion, loss of soil biodiversity, soil pollution, soil compaction, leaching of organic matter, soil siltation, and others.

Soil degradation in one form or another occurs in almost all countries of the world. Globally, about 10 to $20 \%$ of dry land and $24 \%$ of global production land are degrading. The key processes of soil degradation are erosion, salinization and water logging, compaction and solid cultivation, acidification, loss of soil organic matter, depletion of nutrients in the soil, biological degradation and soil pollution. Water and wind erosion accounted for $84 \%$ of these damages, most of which were the result of inadequate land management in various agricultural systems, both natural and mechanized.

The European Union is losing 970 million tons of soil per year due to water erosion, equivalent to a 1-meter loss of soil from an area the size of Berlin or enough to cover an area twice as large as Belgium with one centimeter of soil.

Currently, land degradation is worth about $\$ 490$ billion per year, which far exceeds the budget for action to prevent it. About $40 \%$ of the world's degraded lands are in areas with the highest poverty levels. Land degradation directly affects the health and livelihoods of approximately 1.5 billion people.

Conducted by the Russian Registry analysis of reports received from the constituent entities of the Russian Federation on the state and use of land for 2015 on their qualitative and environmental status shows that land degradation is observed almost everywhere in Russia.

The main negative processes leading to land degradation, soil and vegetation are water and wind erosion, waterlogging, flooding, salinity and alkalinity, land disturbance. Water erosion is affected by $17.8 \%$ of agricultural land, by wind $-8.4 \%$, waterlogged and swampy lands occupy $12.3 \%$, saline $-20.1 \%$ of agricultural land.

Desertification of land is currently one of the most intense and widespread processes in the arid areas of the south of the Russian Federation. As a result of desertification of arid territories, natural pastures lose their productivity, soils undergo erosion and salinization, sands are exposed and set in motion.

In the Russian Federation, desertification to some extent covers 27 subjects of the Russian Federation on an area of more than 100 million hectares.

Ruben N. Lubowski, Andrew J. Planting, Robert N. Stavins showed on the basis of econometric and simulation analysis that private decisions in the field of land use are critically dependent on land quality and are driven by the economic returns of alternative uses, which in some cases are significantly affected by state policy [1].

In accordance with this, we consider it important to use indicators of environmental and economic efficiency to assess the level of land use efficiency in agricultural production.

\section{Methods}

The statistical-economic method was used to study the state of land resources and soil fertility, and to provide the population with food. The monographic method was used to study methods and the level of assessing the effectiveness of land use, ways to preserve and improve soil fertility, balance and calculated-structural methods - to justify the parameters of soil fertility reproduction based on increasing environmental and economic efficiency in order to ensure food security.

\section{The results of the study}


Mistakes in land management in agriculture often become visible when it is too late to avoid consequences. Some land management practices no longer meet the requirements of maintaining soil fertility in a growing global population [2-6]. These include burning plant debris, as well as steaming land. for several years to ensure soil recovery. Making, maintenance and preservation of fertility of various soil types around the world in the face of different climate conditions is today the greatest problem for agriculture.

The key to soil fertility is mainly the humus content of soils. A wide variety of essential nutrients can only be accessed if the soil contains a sufficient proportion of decomposed organic matter. And only then will these nutrients dissolve in water and be absorbed by the plant. There is a direct link between soil health and human health, since $95 \%$ of the food we consume comes from soils. Micronutrient deficiencies are one of the main factors affecting the health and well-being of people around the world, especially in developing countries. More than two billion people suffer from micronutrient deficiencies, in particular vitamins A, iodine, iron and zinc. Existing nutrition systems increasingly have to offer adequate, safe, varied and nutritious food for all, which contributes to a healthy diet.

Food grown in nutrient-depleted soils contributes to systemic human (protein- energy) malnutrition due to the lack of important trace elements in the human diet, such as iron, lithium, magnesium, zinc, copper and iodine. Soil health and its fertility have a direct impact on the nutrient content of food products. Available levels of trace elements in soils are a major factor in determining the content of micronutrients in plants. If the soil has no necessary micronutrients, it has a direct impact on the food system, not delivering a sufficient amount of micro elements to meet human needs. This is especially true for microelements, which are important nutrients for humans, but, as we know, are not essential for plant growth, such as selenium and iodine.

Taking into consideration the indispensability of land as a resource of agricultural production, rational and efficient use of it is today an acute national problem. Ensuring food security of the population directly depends on the competent organization of land use.

Food security, as defined at the World Food Summit in Rome (1996), is a passive state of concern that exists "when all people at all times have physical and economic access to sufficient, safe and nutritious food to satisfy their diet needs and food preferences for an active and healthy life. ". The right to food, as enshrined in the United Nations International Covenant on Economic, Social and Cultural Rights, is defined as the "fundamental right to freedom from hunger," which 164 member states must comply with.

Food security of the Russian Federation is the state of the country's economy, which ensures food independence of the Russian Federation, guarantees the physical and economic accessibility for each citizen of the country of food products that meet the requirements of the legislation of the Russian Federation on technical regulation, in amount less than rational food consumption standards necessary for active and healthy life.

Food safety implies sustainable domestic food production in volumes not less than the established threshold values. Significant risks are agroecological, which are caused by adverse climatic changes, as well as the consequences of natural and man-made emergencies. In this connection, the economic policy in the field of ensuring food security in the sphere of agricultural production, raw materials and food should concentrate, including on areas of increasing soil fertility and productivity. Successful land use is primarily determined by the state of agriculture, the clear implementation of all stages of the technological process.

Factors of increasing economic fertility do not act spontaneously, but with a certain regularity. For example, the use of the most advanced technology for gathering harvest can reduce its losses or, if technologies used degrade the quality of the soil, it will lead to a decrease in yield. The efficiency of the use of agricultural land largely depends on how well the factors ensuring the economic fertility of the land are used. 
The process of reproduction of land fertility is complex and multifaceted, due to the natural and socio-economic characteristics of agricultural production, productive and economic relations in the economy, specific features of the land itself [7-9].

In our opinion, the main principle of the development of the agricultural sector should be the greening of all measures for the development of agriculture, taking into account the natural features of the functioning of land resources. Already in accordance with this principle, it is necessary to regulate measures for mechanization, chemicalization, and implementation of scientific and technological progress.

In the area of environmental protection, there is usually uncertainty in terms of benefits and uncertainty in terms of costs. Therefore, at the moment, further formalization of the assessment of processes occurring in the system of interaction between humans and land in the process of agricultural production is required.

When analyzing the efficiency of agricultural land use, it is important to determine not only economic, but also ecological and economic components. The environmental component of land use can be measured on the basis of the amount of prevented environmental damage caused by soil fertility, and on the basis of the value of the environmental effect that is created within measures to reproduce soil fertility. The effectiveness of measures to prevent it can be assessed at the cost of lost products, the cost of eliminating or reducing damage. The costs of measures for the reproduction of soil fertility represent environmental costs, the effectiveness of which can be estimated by the output of additional agricultural products per unit area [10.11].

For each farm of any form of ownership and category, as well as the region as a whole, it is important to determine annually the effectiveness of land use by individual crops, taking into account the environmental impact on soil fertility.

Most farms provided the growth indicators of economic efficiency of land use, which is explained including by increased crop yields. The main source providing high yields, is the use of chemicals including mineral fertilizers. At the same time, environmental damage is caused to soil fertility, associated with a decrease in soil humus and the content of basic nutrients.

Determination of changes in soil fertility elements can be carried out both in a laboratory way, which is rather problematic for small organizations, and with the help of a normative calculation, the essence of which is to compare the supply and mineralization of humus, in other words, to compare the income and consumption. To do this, you need to know the yield of the main products, the initial humus content in the soil and the coefficients: the yield of plant residues relative to the main product, the coefficient of humification of plant residues and the coefficient of adjustment for natural and climatic conditions.

One of the typical agricultural enterprises of the Tambov region of the Russian Federation with a total land area of about 5 thousand hectares is the state farm of

"Zeleny Gay", the district of Michurinsk, which has sufficient land resources for successful agricultural activities. These lands are environmentally friendly, as well as products produced.

In the production of grain crops, a negative balance of soil humus is observed, its unrefilled part (UP) annually amounts to 1.707 tons per 1 ha. The coefficient of humification of manure for the Central Black Soil Region is 0.2. Knowing this, it can be determined that to compensate the loss of humus, standard manure should be introduced:

$$
\mathrm{LA}=\mathrm{UP}: 02 \text {; }
$$

where: LA- level of necessary application of organic fertilizers, $\mathrm{LA}=1.707: 0.2=8.5 \mathrm{t}$ per 1 ha. 
The costs of using organic fertilizers will be the cost equivalent of reducing soil fertility (CEF.):

$$
\mathrm{CEF}=\mathrm{LA} \times \mathrm{COF}
$$

where: COF - the cost of 1 ton of organic fertilizers, rubles.

$\mathrm{CEF}=8.5 \times 350=2975$ rubles. on 1 ha

Determination of changes in the content of basic nutrients in the soil (using a normative calculation) indicates a negative balance of nutrients in the cultivation of crops (yield 20.1c per $1 \mathrm{ha}$ ), as at a total flow nutrition elements 139,4 kg.a.s. the increase with plant residues and fertilizers is $61.0 \mathrm{~kg}$.a.s. Positive balance of nutrients requires the addition of 78.4 kg.a.s. (Table 1).

Table 1.The balance of the elements in the cultivation of crops

\begin{tabular}{|c|c|c|c|c|c|}
\hline \multirow{2}{*}{$\begin{array}{c}\text { Nutri } \\
\text { ents }\end{array}$} & \multirow{2}{*}{$\begin{array}{l}\text { Consumption } \\
\text { of NPK, kg.a.s. }\end{array}$} & \multicolumn{2}{|c|}{ Increase of NPK, kg.a.s. . } & \multicolumn{1}{|c|}{$\begin{array}{c}\text { Total } \\
\text { addition } \\
\text { kg.a.s. }\end{array}$} & $\begin{array}{l}\text { Excess } \\
\text { lack } \\
\text { nutrients, } \\
\text { kg.a.s. }\end{array}$ \\
\cline { 3 - 6 } & & $\begin{array}{c}\text { plant } \\
\text { residues }\end{array}$ & $\begin{array}{c}\text { mineral } \\
\text { fertilizers }\end{array}$ \\
\hline $\mathrm{N}$ & 65 & 0.4 & 23.0 & 23,4 & -41.6 \\
\hline $\mathrm{P}$ & 28.4 & 0.2 & 18.5 & 18.7 & -9.7 \\
\hline $\mathrm{K}$ & 46 & 0.4 & 18.5 & 18.9 & -27.1 \\
\hline Total & 139.4 & 1,0 & 60.0 & 61 & -78.4 \\
\hline
\end{tabular}

Sunflower cultivation (yield 11.7 centners per 1 ha) is also accompanied by a negative balance of nutrients, because at a total flow rate of the nutrients $174.2 \mathrm{~kg}$.a.s. the increase is 67.9 kg.a.s. Positive balance of nutrients requires the additional $106.3 \mathrm{~kg}$.a.s. (table 2).

Table 2.The balance of the nutrients in the cultivation of sunflower

\begin{tabular}{|c|c|c|c|c|c|}
\hline \multirow{2}{*}{$\begin{array}{l}\text { Nutrien } \\
\text { ts }\end{array}$} & \multirow{2}{*}{$\begin{array}{c}\text { Consumption } \\
\text { of NPK, kg.a.s. }\end{array}$} & \multicolumn{2}{|c|}{ Increase of NPK, kg.a.s. } & \multicolumn{1}{|c|}{$\begin{array}{c}\text { Total } \\
\text { additione } \\
\text { kg.a.s. }\end{array}$} & $\begin{array}{l}\text { Excess (+) } \\
\text { lack } \\
\text { nutrients, } \\
\text { kg.a.s. }\end{array}$ \\
\cline { 3 - 6 } & & $\begin{array}{c}\text { plant } \\
\text { residues }\end{array}$ & $\begin{array}{c}\text { mineral } \\
\text { fertilizers }\end{array}$ & & -23.4 \\
\hline $\mathrm{N}$ & 47.8 & 0.2 & 24.2 & 24.4 & -16.5 \\
\hline $\mathrm{P}$ & 38,2 & 0.1 & 21.6 & 21.7 & -66.4 \\
\hline $\mathrm{K}$ & 88.2 & 0.2 & 21.6 & 67.9 & 106.3 \\
\hline Total & 174.2 & 0.5 & 67.4 & & \\
\hline
\end{tabular}

Let us calculate the balance of nutrients in the cultivation of crops, taking into account the introduction of the estimated dose of organic fertilizers.

Then the total supply of nutrients will be:

$$
\mathrm{AT}=\sum \mathrm{Li} \text { A iI NPK }
$$

where : A NPK - the addition of the species I (with plant residues, mineral fertilizers, organic fertilizers ) .

The additional of nutrients with organic fertilizers (A org NPK) will:

$$
\text { A org NPK }=\text { LA } \times \text { 0,35 } \times \text { Ccont }
$$

where Ccont are the coefficients of the contents of nutrients in 1 ton of standard manure: $\mathrm{N}-5, \mathrm{P}-2.5, \mathrm{~K}-6$ kg.a.s.

0.35 is the coefficient of assimilation of nutrients from manure (in the 1 st year $35 \%$ of nutrients are absorbed).

Table 3.The Balance of nutrients in the cultivation of crops taking into account the application of organic fertilizers 


\begin{tabular}{|c|c|c|c|c|c|c|}
\hline \multirow{2}{*}{ nts } & \multirow{2}{*}{$\begin{array}{l}\text { Consumpt } \\
\text { ion of NPK, } \\
\text { kg.a.s. }\end{array}$} & \multicolumn{3}{|c|}{ Increase of NPK, kg.a.s. } & \multirow[b]{2}{*}{$\begin{array}{c}\text { Tota } \\
1 \\
\text { additione } \\
\text { kg.a.s. }\end{array}$} & \multirow[b]{2}{*}{$\begin{array}{c}\text { Exce } \\
\text { ss }(+) \\
\text { lack }(-) \\
\text { nutrients, } \\
\text { kg.a.s. }\end{array}$} \\
\hline & & $\begin{array}{l}\text { vegetable } \\
\text { leftovers }\end{array}$ & $\begin{array}{l}\text { mineral } \\
\text { fertilizers }\end{array}$ & $\begin{array}{lr} & \text { organi } \\
\text { c } & \\
& \text { fertiliz } \\
\text { ers } & \end{array}$ & & \\
\hline $\mathrm{N}$ & 65 & 0.4 & 23.0 & 14.9 & 38.3 & -26.7 \\
\hline $\bar{P}$ & 28,4 & 0.2 & 18.5 & 7.4 & 26.1 & $-2,3$ \\
\hline $\mathrm{K}$ & 46 & 0.4 & 18.5 & 17.9 & 36.8 & -9.2 \\
\hline Total & 139.4 & 1,0 & 60.0 & 40,2 & 101,2 & -38.2 \\
\hline
\end{tabular}

The addition of nutrients with 3 sources does not provide positive balance of nutrients as due to a total consumption of nutrients (139.4 kg.a.s.), the input is $101.2 \mathrm{~kg}$.a.s. However positive balance of nutrients requires the addition of $38.2 \mathrm{~kg}$.a.s. for crops (Table 3 ) and $66.1 \mathrm{~kg}$.a.s. for sunflower (table 4).

Table 4. Balance of nutrients in the cultivation of sunflower taking into account the application of organic fertilizers

\begin{tabular}{|c|c|c|c|c|c|c|}
\hline \multirow[t]{2}{*}{ Nutrients } & \multirow{2}{*}{$\begin{array}{l}\text { Consumption } \\
\text { of NPK, kg.a.s. }\end{array}$} & \multicolumn{3}{|c|}{ Increase of NPK, kg.a.s. } & \multirow{2}{*}{$\begin{array}{l}\text { Total } \\
\text { additione } \\
\text { kg.a.s. }\end{array}$} & \multirow{2}{*}{$\begin{array}{l}\text { Excess (+) } \\
\text { lack (-) } \\
\text { nutrients, } \\
\text { kg.a.s. }\end{array}$} \\
\hline & & $\begin{array}{l}\text { vegetable } \\
\text { leftovers }\end{array}$ & $\begin{array}{l}\text { mineral } \\
\text { fertilizers }\end{array}$ & $\begin{array}{l}\text { organic } \\
\text { fertilizers }\end{array}$ & & \\
\hline $\mathrm{N}$ & 47.8 & 0.2 & 24.2 & 14.9 & 39.3 & -8.5 \\
\hline $\mathrm{P}$ & 38,2 & 0.1 & 21.6 & 7.4 & 29.1 & -9.1 \\
\hline $\mathrm{K}$ & 88.2 & 0.2 & 21.6 & 17.9 & 39.7 & -48.5 \\
\hline Total & 174.2 & 0.5 & 67.4 & 40,2 & 108.1 & -66.1 \\
\hline
\end{tabular}

The consumption of nutrients within the crop exceeds the addition, therefore, the crop is formed due to removal from the soil, reducing its fertility. The cost equivalent before adding mineral fertilizers is the damage caused by a decrease in soil fertility. A positive balance of nutrients requires a supplement of $78.4 \mathrm{~kg}$.a.s. per 1 hectare cultivated area of cereals (considering manure $38.2 \mathrm{~kg}$.a.s.) for sunflower $106.3 \mathrm{~kg}$.a.s. per 1 ha of cultivated area (taking into account the application of $66.1 \mathrm{~kg}$.a.s. organic fertilizers) Observance of the conditions for maintaining a non-negative balance of humus in the soil makes it necessary to use the option of compensating for the loss of fertility elements, with the use of both organic and mineral fertilizers. The cost equivalent of adding the required number of nutrients (Cad NPK) will be:

$$
\mathrm{Cad} \text { NPK }=|\mathrm{UNPK}| \times \mathrm{CbNPK}
$$

where: CbNPK is the unrepaired portion of the nutrients;

$\mathrm{C} \mathrm{m}$ NPK is the cost of making $1 \mathrm{~kg}$ a.v. mineral fertilizers.

Cad NPK $=38.2 \times 22=840.4$ rubles per 1 ha of grain

$\mathrm{Cad}$ NPK $=66.1 \times 22=1454.2$ rubles for 1 ha of sunflower

Environmental damage when cultivating crops (Ed):

$$
\mathrm{Ed}=\mathrm{CEF}+\mathrm{C} b \mathrm{NPK}
$$

$\mathrm{Ed}=2975+840.4=3815.4$ rubles per 1 ha of grain

$\mathrm{Ed}=2975+1454.2=4429.2$ rubles per 1 ha of sunflower

Environmental damage during the cultivation of crops on the state farm of "Zelehy Gay" the district of Michurinsk Tambov region taking into account the calculations amounted to 3815.48 rubles per 1 ha, the cultivation of sunflower amounted 4429.2 rubles per 1 ha. 
Ecological and economic efficiency of crop cultivation will make the difference between the net income from production and environmental damage:

$$
\text { E-Eeff }=\text { NI - Ed; }
$$

where: E-Eeff - ecological and economic efficiency of crop cultivation; NI - net income of crop cultivation, rubles;

E-Eeff $=1837-3815.4=-1978.4$ rubles per 1 ha of sown area of grain crops.

$\mathrm{E}$-Eeff $=13347-4429.2=8917.8$ rubles per 1 ha of sunflower sown area

As the study shows, the cultivation of crops, taking into account the actual supply of nutrients, causes a negative balance of nutrients in the soil, i.e. within a relative level of profitability of the use of land resources, the environmental and economic efficiency of their use was negative in the cultivation of grain in the economy and less than the net income in the cultivation of sunflower. The calculation of environmental and economic efficiency indicates the need not only for the joint application of organic and mineral fertilizers in optimal parameters, but also for the search for alternative ways to ensure the reproduction of soil fertility and a positive balance of nutrients, taking into account their removal by crop. Ensuring a positive humus balance should be not only after the culture of the first year of applying organic fertilizers to the steam predecessor, but also for subsequent crop rotation crops, taking into account the humus mineralization coefficient.

In the short term, one of the really economically viable ways of ensuring a suspension of soil fertility and increasing agricultural production along with the use of artificial means will be the biologization of agriculture, which involves, in addition to a more complete use of all resources, traditional organic fertilizers and biological nitrogen, the use of soilprotective crop rotation, plowing green manure and excess straw into soil.

Due to the impossibility in the near future to fully replenish the removal of nutrients through mineral and organic fertilizers, in the farms of the region special attention should be paid to the structure of sown areas and the rotation of crops in crop rotation. With the proper selection of crops without violating the principle of fertilization, it is possible to regulate the processes of accumulation and decomposition of organic matter, thereby improving the balance of humus and increasing fertility.

Legumes have the most favorable effect on the soil; they have a positive effect not only on the balance of humus, but also enrich the soil with biological nitrogen. However, there are fewer fodder crops on the farms of the region, in which significant areas were occupied by legumes. At the same time, the areas of industrial crops have increased and it has a great effect on the mineralization of soil organics.

Limited financial resources do not often allow producers to fully implement a range of activities to maintain soil fertility [12-17]. There is no alternative to the use of fertilizers, however, in modern conditions, a new environmental and economic principle is needed, which provides a proportional investment of material and labor costs in technogenic, environmental and biological factors. Green manure siderates, which proved the effectiveness of implementation earlier are of great importance for the farms that do not have a sufficient amount of organic fertilizer. These siderates demonstrate high performance on infertile sandy soils. However, they are more effective on sandy and loamy soils. Sowing green manure crops for green manure in the fallow field increases the supply of soil humus, improves the physical, chemical and biological properties of the soil, and this, in its turn, has a positive effect on the yield of winter wheat and other crops in the rotation.

Green manure (also called green manure fertilizer) - is a fresh plant mass, plowed into the soil for enrichment of organic matter and nitrogen. They allow to improve the water, air and thermal conditions of the soil. They are environmentally friendly, cost-effective, based on the use of solar energy resources for the production of organic fertilizers. 
Sowing siderates is the main way to restore humus in depth. This agrotechnical measure repeats natural processes, since in natural conditions humus is formed mainly as a result of decomposition of the plant root system. When the roots of plants decompose, channels are formed in the soil, and thereby the porous structure is restored. This is the most important function of using siderates as an improvement in the structure and accumulation of humus in the soil, which in its turn has a positive effect on the yield of winter crops and other crops in crop rotation.

The best sideral crops nowadays include: lupine, white mustard, rye, vetch (spring), buckwheat, fatseliya, rape, rapeseed and others, due to agrotechnical requirements for the efficient use of land resources and the natural and climatic conditions of the region. The effectiveness of the project for the use of sideral vapors of a number of other measures with the aim of preserving and restoring soil fertility was examined by us taking into account a number of agricultural organizations.

In the modern world, more and more attention is paid to agroecology systems [18-21]. Agroecological concepts are based on taking into account the natural features of the functioning of land resources. The system of agroecology is a combination of environmental, biological and agricultural sciences, along with medicine, nutritional and social sciences.

Agroecology has three aspects. They are:

1. scientific discipline, including a holistic analysis of agroecosystems, including elements of humans and the environment.

2. a set of principles and practices to enhance the environmental, socio-economic and cultural sustainability of agricultural systems.

3. the search of a new way for treating agriculture and its relationship with society.

In the report "Agroecology and the Right to Food" made by the United Nations special reporter Olivier de Schutter, agroecology is defined as follows: Agroecology is both a science and a multitude of practices. It was created by bringing together two scientific disciplines: agronomy and ecology. As a science, it is "the application of environmental science for studying, developing and managing sustainable agroecosystems." As a set of agricultural methods, agroecology seeks to strengthen agricultural systems by imitating the natural process, creating thereby beneficial biological interactions and synergies between ecosystem components. Agroecology increases productivity locally; reduces poverty in rural areas; agroecological practices contribute to improved nutrition and adaptation to climate changes.

In the declaration of the International Forum on Agroecology (2015), agroecology is defined as a fundamental way of resisting the economic system, which increases the economic benefits to life. Agroecology is based on such environmental principles as the reproduction of microorganisms in the soil, nutrient recycling, dynamic biodiversity management and energy conservation at all scales.

Agroecology involves reducing the use of external materials that can only be purchased in industry. It does not use agrotoxins, artificial hormones, transgenic or other harmful technologies.

\section{Conclusion}

As the study shows, the cultivation of crops, taking into account the actual supply of nutrients, often causes a negative balance of nutrients in the soil, i.e. if there is a relative level of profitability of land use, the environmental and economic efficiency of their use is negative. The calculation of environmental and economic efficiency indicates the need not only for the joint application of organic and mineral fertilizers in optimal parameters, but 
also for the search of alternative ways to ensure the reproduction of soil fertility and a positive balance of nutrients, taking into account their removal by crop.

In the current agricultural conditions, preservation and rational use of soil fertility including the principles of biologization and agroecology can fulfil its main task sustainable food production and ensuring their physical and economic accessibility for every citizen of the country.

\section{References}

1. R. N. Lubowski, A. J. Plantinga, R. N. Stavins, What drives land-use change in the United States? A national analysis of landowner decisions, Land Economics, 84(4), 529-550 (2008) doi:10.3368/le.84.4.529

2. O. R. Andriamihaja, F. Metz, J. G. Zaehringer, M. Fischer, P. Messerli, Identifying agents of change for sustainable land governance, Land use Policy, 100 (2021) doi:10.1016/j.landusepol.2020.104882

3. O. De Schutter, The emerging human right to land, International Community Law Review, 12(3), 303-334 (2010) doi:10.1163/187197310X513725

4. N. O. Keohane, R. L. Revesz, R. N. Stavins, The choice of regulatory instruments in environmental policy. Environmental law, 491-545 (2019) doi:10.4324/9781315194288-10 Retrieved from www.scopus.com

5. R. G. Newell, A. B. Jaffe, R. N. Stavins, The induced innovation hypothesis and energy-saving technological change, Technological change and the environment, 97126 (2010) Retrieved from www.scopus.com

6. A. Nikitin, N. Kuzicheva, N. Karamnova, Establishing efficient conditions for agriculture development, International Journal of Recent Technology and Engineering, 8(2), 1-6 (2019) doi:10.35940/ijrte.B3744.078219

7. I. N. Donskikh \& E. V. Voropaeva, Composition and properties of humic acids from light gray forest soil with different fertilizing systems, Eurasian Soil Science, 33(1), 65-71 (2000) Retrieved from www.scopus.com

8. F. R. Zaidelman, A. S. Nikiforova, L. V. Stepantsova, V. N. Krasin, S. B. Safronov, Ecological-hydrological and genetic features of chernozem-like soils of closed depressions in the northern Tambov lowland, Eurasian Soil Science, 41(2), 176-189 (2008) doi:10.1134/s1064229308020099

9. F. R. Zaidel'man, A. S. Nikiforova, L. V. Stepantsova, T. V. Krasina, V. N. Krasin, Concretions in typical chernozem, gleyed chernozem-like, and solonetzic chernozemlike soils of the southern Tambov lowland, Eurasian Soil Science, 47(6), 540-555 (2014) doi:10.1134/S1064229314060118

10. A. A. Dubovitski, E. K. Karpunina, E. A. Klimentova, N. V. Cheremisina, Ecological and economic foundations of effective land use in agriculture: The implementation prospects of food security. Paper presented at the Proceedings of the $33 \mathrm{rd}$ International Business Information Management Association Conference, IBIMA 2019: Education Excellence and Innovation Management through Vision 2020, 26872693 (2019) Retrieved from www.scopus.com

11. A. A. Dubovitski, E. A. Klimentova, Ecological and economic efficiency of land resources use: methodical aspect, Economics of agriculture of Russia, 5, 2-6 (2020) doi: $10.32651 / 205-2$ 
12. E. K. Karpunina, G. K. Lapushinskaya, A. E. Arutyunova, S. V. Lupacheva, A. A. Dubovitski, Dialectics of Sustainable Development of Digital Economy Ecosystem. Institute of Scientific Communications Conference ISC 2019: Scientific and Technical Revolution: Yesterday, Today and Tomorrow, 486-496 (2020) https://doi.org/10.1007/978-3-030-47945-9_54

13. A. Nikitin, E. Klimentova, A. Dubovitski, Impact of small business innovation activity on regional economic growth in Russia, Revista Inclusiones, 7, 309-321 (2020) Retrieved from www. https://publons.com

14. E. A. Myagkova, Innovative and investment strategy of agricultural organizations development, Ecology, Environment and Conservation, 21, 13-17 (2015) Retrieved from www.scopus.com

15. A. V. Nikitin, M. S. Kaliuzhnyi, V. A. Solopov, Innovative village - A new model of bioeconomy, Ecology, Environment and Conservation, 21, 19-22 (2015) Retrieved from www.scopus.com

16. A. V. Nikitin, S. N. Trunova, V. A. Voropaeva, The assessment of the effectiveness of the implementation of scenarios for the sustainable development of agriculture, International Journal of Innovative Technology and Exploring Engineering, 8(10), 3002-3005 (2019) doi:10.35940/ijitee.J8871.0881019

17. E. Popkova, S. Meshkova, E. Karpunina, E. Karpushko, M. Karpushko, Developing countries as new growth poles of post-crisis global economy, Contemporary Economics, 10(2), 175-186 (2016) doi:10.5709/ce.1897-9254.208

18. S. Gliessman, Evaluating the impact of agroecology, Agroecology and Sustainable Food Systems, 44(8), 973-974 (2020) doi:10.1080/21683565.2020.1774110

19. S. R. Gliessman, Transforming food and agriculture systems with agroecology, Agriculture and Human Values, 37(3), 547-548 (2020) doi:10.1007/s10460-020-10058-0

20. M. González-Chang, S. D. Wratten, M. W. Shields, R. Costanza, M. Dainese, G. M. Gurr, W. Zhou, Understanding the pathways from biodiversity to agro-ecological outcomes: A new, interactive approach. Agriculture, Ecosystems and Environment, 301 (2020) doi:10.1016/j.agee.2020.107053

21. L. Marchetti, V. Cattivelli, C. Cocozza, F. Salbitano, M. Marchetti, Beyond sustainability in food systems: Perspectives from agroecology and social innovation, Sustainability (Switzerland), 12(18) (2020) doi:10.3390/su12187524 